\title{
Cutaneous Lipoma
}

National Cancer Institute

\section{Source}

National Cancer Institute. Cutaneous Lipoma. NCI Thesaurus. Code C4616.

A benign adipose tissue neoplasm of the skin. 